\title{
Eszterházy Károly korának katolikus megújulási törekvései
}

A katolikus egyháztörténeti kutatás az utóbbi néhány évtizedben Európa-szerte megélénkült, $s$ a konfesszionalizáció fogalmának bevezetése révén szemléletében és módszereiben is megújult, mint ahogy erről a téma igen bőséges szakirodalma tájékoztatást nyújt. ${ }^{1}$ A reformáció-ellenreformáció sematikus dichotómiája helyett a hitújítási mozgalmak pluralitására irányult a figyelem, ebben a keretben pedig a katolikus megújulási törekvések kutatása is új pozícióba került. Számos nemzetközi konferencia már ennek a felfogásnak a jegyében zajlott le, többször is elhangzott, hogy a konfesszionális egyoldalúság helyett a felekezeti szempontok komparatív vizsgálata révén alakítható ki a korábbiaknál hitelesebb kép a kora újkor keresztény egyháztörténetéről. ${ }^{2} \mathrm{Az}$ alapfogalmak (reform, reformáció, ellenreformáció, rekatolizáció, poszttridentinizmus stb.) korszerű értelmezése újabban nemzetközi vitaülések tárgya lett, ehhez Luther fellépésének fél évezredes évfordulója újabb impulzusokat adott. ${ }^{3} \mathrm{~A}$ római katolikus egyházon belüli megújulási törekvéseknek az eddigieknél árnyaltabb számba vételét elsősorban a német egyháztörténeti kutatás kezdeményezte és képviselte, a magyar kutatás csak jóval később kezdte ennek eredményeit kamatoztatni. Célszerű Eszterházy Károly kiemelkedő egyházszervezői

1 Die katholische Konfessionalisierung. Hg. Wolfgang Reinhard - Heinz Schilling. Münster 1995; Wolfgang Reinhard: Konfession und Konfessionalisierung in Europa. Berlin 1997; Konfessionalisierung in Ostmitteleuropa. Hg. Joachim Bahlcke - Arno Strohmeyer. Stuttgart 1999; Balázs Mihály: Az alkalmazás dilemmái. A német konfesszionalizációs modell és az erdélyi reformáció. In: Konfesszionalizáció. Felekezetiség és politikum a kora újkorban. Korall, 57 (2014), 5-26.; Carlos Eire: Reformations. The Early Modern World 1450-1650. Yale U. P., New Haven 2016; Vorwort. In: Ernst Walter Zeeden (1916-2011) als Historiker der Reformation, Konfessionsbildung und „deutschen Kultur”. Relektüren eines geschichtswissenschaftlichen Vordenkers. Hg. Markus Gerstmeier - Anton Schindling. Vorwort, Aschendorff, Münster 2016. 14-15. (KLK 76).

2 Az ökumenizmus szempontjait érvényesítő, korszerű felfogásban szerveződő konferencia zajlott le többek között Kolozsváron: https://keresztenyszo.verbumkiado.ro/archivum/2017/december/11. html, letöltés 2018. febr. 11. A konferencia kötete sajtó alatt.

3 John O'Malley: Trent and all that. Renaming Catholicism in Early Modern Era. Cambridge/MA -London 2000. 119-125. A fogalmak értelmezésével foglalkozó konferenciák egyike: Katholische Reformationen. Tagung an der Bischöflichen Akademie Aachen, 17. / 18. Februar 2018. https:// www.reforc.com/wp-content/uploads/2018/01/Konzept-Tagung-kurz-Wissenschaftler.pdf, letöltés 2018. jan. 31 . 
és tudománypártoló tevékenységét is ebben a kutatási keretben szemügyre venni, teljesítményét az újabb szakirodalom által képviselt és előtérbe állított történeti paradigmák koordinátái között elhelyezni és mérlegelni.

Peter Hersche berni történész friss eszmefuttatása szerint a katolikus egyház történetében három kiemelkedő jelentőségű megújulási korszakot lehet megkülönböztetni, ezek: 1. a 16. századi protestáns kihívásokra adott válaszok ideje, a hitről folytatott vitákban kialakuló egyházszerveződés, azaz a konfesszionalizáció ('Konfessionsbildung') folyamata, a Tridentinum hatása; 2. a felvilágosodás kori toleranciaelv és reformkatolicizmus (janzenizmus, muratorianizmus, gallikanizmus) periódusa; 3. a II. Vatikáni Zsinat utáni korszak (belső megújulás, ökumenizmus). ${ }^{4}$

Ha ezt a sémát vesszük alapul, akkor Eszterházy kora a magyarországi katolikus egyháztörténetnek abba a periódusába esik, amelyikben másodszorra nyílt meg a lehetősége az egyházi szervezet megújításának és a spirituális gondolkodás modernizálásának. Erről a lehetőségről a szakirodalomban különböző vélemények láttak napvilágot, a felvilágosodás és a katolicizmus viszonyának kérdése a nemzetközi eszmecserékben már hosszú évtizedek óta vitatéma. Eduard Winter monográfiái az 1960-as évek óta napirenden tartották a „felvilágosodott reformkatolicizmus” fogalmát, majd az 1976ban Peter Hersche által szerkesztett kötet az osztrák példa révén vizsgálta, hogy mit takar ez az eszme- és egyháztörténeti megjelölés. ${ }^{5}$ Kosáry Domokos vitatta ennek alkalmazhatóságát, $s$ Winter koncepcióját kritizálva, a korszerü tendenciák megjelenését főként a protestantizmus szellemi horizontjában vélte felfedezhetőnek, nem túl sok progresszív kezdeményezést tulajdonítva a magyarországi katolicizmusnak. ${ }^{6}$

Az újabb és árnyaltabb elemzések arra utalnak, hogy a felvilágosodás különböző aspektusai a Kárpát-medencén belül, főként egyes szerzetesrendek (mindenekelőtt a piaristák) aktivitásában mutathatók ki, míg a katolikus klérus többnyire defenzívába szorult egyrészt római orientációjú barokk tradicionalizmusa, másrészt a teréziánus-jozefinista egyházpolitikával szemben kialakult ellenállása miatt, ezért csak részben tudta átvenni az újító szellem eredményeit. ${ }^{7}$ A korszak prédikációszerzéséről

4 Das Konzil von Trient und die katholische Konfessionskultur (1563-2013). Wissenschaftliches Symposium aus Anlass des 450. Jahrestages des Abschlusses des Konzils von Trient. Freiburg in Breisgau, 18-21. September 2013 Hg. von Peter Walter - Günther Wassilowsky. Aschendorff, Münster 2016. 569. (Reformationsgeschichtliche Studien und Texte, Bd. 163).

5 Eduard Winter: Frühaufklärung. Berlin 1966. 211; Der aufgeklärte Reformkatholizismus in Österreich. Hg. Peter Hersche. Historisches Institut der Universität Bern - P. Lang Verlag. Bern 1976. (Quellen zur neueren Geschichte, Bd. 33); Bernard Plongeron: Was ist Katholische Aufklärung? In: Katholische Aufklärung und Josephinismus. Hg. von Elisabeth Kovács. Verlag für Geschichte und Politik, Wien 1979. 11-56.

6 Kosáry Domokos: Művelődés a 18. századi Magyarországon. Akadémiai Kiadó, Bp. 1980. 183-285.

7 Forgó András: Egyház, rendiség, politikai kultúra. Papok és szerzetesek a 18. század országgyülésein. Szent István Társulat, Bp. 2017. 339-340. 
készült értekezés azonban nemrég meggyőzően mutatta ki, hogy a magyar katolikus hitszónokok hangvételét is módosították a 18. század második felében megjelenő új eszmeáramlatok, nagy hangsúly esett a babonák elítélésére, a népi kegyesség vadhajtásainak, a túlzott ereklyekultusznak a visszaszorítására, a hitélet gyakorlatiasabbá tételére. ${ }^{8} \mathrm{Ma}$ is aktuális kérdés tehát, hogy a 18 . századi magyar fôpapság mit tudott átvenni a felvilágosodás - legtágabban értelmezett - gondolatköréből, szellemi eredményeiből, mentalitásából. A kérdés úgy is feltehető: mennyiben jelentkezett belső igény a megújulásra, milyen belátások vezettek ezekhez, s ugyanakkor milyen külső tényezők, újabb eszmeáramlatok, kihívások és modernebb gondolati megfontolások inspirálták vagy éppen kényszerítették ki a reformelképzeléseket és törekvéseket. A Tridentinum kétségtelen jele volt az újraszerveződés eszméjének, a 18. század viszont újabb társadalmi mozgásokat implikált, most már ezeknek a hálózatában tradíció és modernizáció feszültségében - kellett pozíciójukat védelmező megoldásokat találniuk a katolikus egyház vezetőinek.

A felvilágosodás korának egyes radikális gondolkodóinál felbukkanó ateizmussal érthető módon szemben állt a katolicizmus, viszont megjelent a bel-

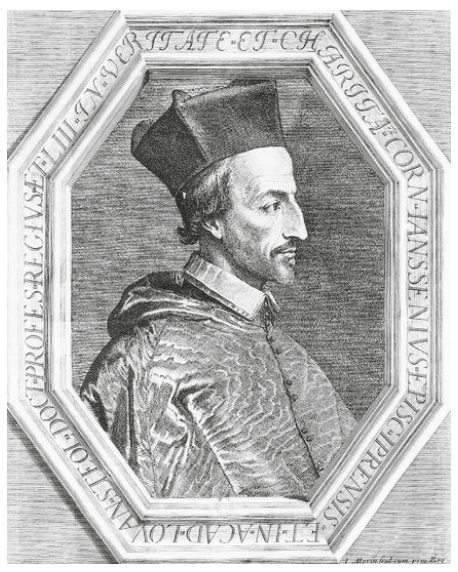

1. kép: Cornelius Jansenius ső egyházkritika és az új tudományos eredményeket kamatoztató, hit és ráció egyeztetését célzó megfontolások különböző - rejtett vagy nyíltabb - formákban. A poszttridentinus teológiával és egyházértelmezéssel konfrontálódva, a janzenizmus révén bukkantak fel elöször olyan nézetek, amelyek rést ütöttek a trienti szellem védőburkán, és katolicizmuson belüli teológiai és politikai vitákhoz vezettek. ${ }^{9}$ Noha Cornelius Jansenius (1585-1638) yperni püspök, löveni egyetemi tanár eredetileg az augustinusi kegyelemtan korszerű értelmezésére törekedett, nézetei túlhaladták a teológia kereteit, s a gallikán államelmélethez közeledtek.

A római kúria elhatárolódott Jansenius követőitől, XI. Kelemen pápa Unigenitusbullája pedig 1713-ban véglegesen eretnekké nyilvánította a németalföldi teológus

8 Lukácsi Zoltán: Szószék és világosság. A magyar katolikus prédikáció a felvilágosodás korában. ELTE, PhD-értekezés, 2010. http://docplayer.hu/amp/21520699-Doktori-disszertacio.html\#show_full_ text, letöltés 2018. febr. 15.

9 A Concilium Tridentinum magyarországi hatásáról a legújabb eredményeket közreadó kötet: Das Trienter Konzil und seine Rezeption im Ungarn des 16. und 17. Jahrhunderts. Hg. Márta Fata - András Forgó - Gabriele Haug-Moritz - Anton Schindling. Aschendorff, Münster 2019. (Reformationsgeschichtliche Studien und Texte, Bd. 171) 
nézeteit. Ennek ellenére Európa-szerte megoszlott a teológusok véleménye, sokan filojanzenistának bizonyultak, egyes tételekkel rokonszenveztek, másokat vitára érdemesnek tartottak. Sokfelé ágazó mozgalom alakult ki így, ${ }^{10}$ amely magában hordozta a katolicizmuson belüli modernizációs törekvések lehetőségét. A francia forradalmi eszmékkel ugyan konfrontálódtak a janzenizmus követői, ${ }^{11}$ a katolikus egyház azonban mégsem tolerálta őket.

A mozgalom magyarországi recepciójáról Zolnai Béla közismert alapvető tanulmányai után viszonylag csekély számú kutatás szólt, részletesebb ismereteket inkább csak Berecz Ágnes fóként könyvtörténeti szempontú értekezése hozott. ${ }^{12}$ Korábbi, csupán az itáliai könyvészeti kapcsolatokra koncentráló áttekintésünk alapján annyi állapítható meg, hogy az egri püspöki könyvtár anyagában a janzenizmussal rokonszenvező, annak tételeit tárgyaló vagy éppen azokat vitató munkák egész sora volt jelen, s ez szembetűnően utal a könyvbeszerzés tágas szemhatárára, a kitagadott eszmeáramlatnak legalábbis az ellenkezéssel párosult tudomásul vételére, a korszak aktuális kérdéseivel való szembesülés kényszerére vagy éppen igényére. ${ }^{13}$ Legszélesebb horizonton Tüskés Gábor tanulmánya térképezte fel a mozgalom kutatásának európai helyzetét, megállapítása szerint: „Az újabb kutatások egy térben és időben rendkívül tagolt, folyamatosan változó, különböző törekvéseket magában foglaló, komplex jelenségegyüttesnek tekintik a mozgalmat, amely nem leegyszerűsíthető a kegyelemtan körüli vitákra”, ezért indokolt „janzenizmusok”-ról beszélni, vagy még inkább a „kereszténység augustinusi modelljének 17. századi változata” kifejezést használni. ${ }^{14}$

A 18. század második felének további - már inkább spirituális, mint teológiai vagy egyházkormányzati - szellemi mozgalma, a muratorianizmus már jóval egyértelműbb és elfogadhatóbb megújulási lehetőséget kínált a katolikus devóció számára. A milánói Biblioteca Ambrosiana könyvtárőre, Antonio Muratori (1672-1750) történeti, teológiai, hagiográfiai, erkölcstani művei révén Európa-szerte jelentékeny teret hódított, a magyarországi klérus gondolkodására is hatott, mivel kötetei nagy

10 Kosáry D.: Mủvelődés a 18. századi Magyarországon i. m. 287.

11 Peter Hersche: Les jansénistes en Autriche et en Allemagne face à la Révolution. In: Jansénisme et Révolution. Paris 1990. (Chroniques de Port-Royal 39)

12 Hölvényi György: Katholische Aufklärung und Jansenismus in Ungarn, in. In: Katholische Aufklärung und Josephinismus. Hg. Elisabeth Kovács. Verlag für Geschichte und Politik, Wien 1979. 93-106; Berecz Ágnes 2006-ban megvédett értekezése bőséges szakirodalommal: http:// doktori.bibl.u-szeged.hu/273/1/de_2855.pdf, letöltés, 2018. febr. 15.

13 Bitskey István: Janzenizmus és ortodoxia. Az egri püspöki könyvtár olasz anyaga a felvilágosodás korában. In: Magyar Könyvszemle 98 (1982), 60-67.

14 A legújabb eredményeket ismertető, alapvető kutatástörténeti áttekintés: Tüskés Gábor: A janzenizmus kutatásának néhány kérdéséhez. In: Irodalomtörténeti Közlemények 119 (2015), $161-180$. 
számban kerültek be a püspöki bibliotékákba, így az egri könyvtár polcaira is. Erről bőséges szakirodalom tájékoztat, ehelyütt elegendő erre utalnunk. ${ }^{15}$

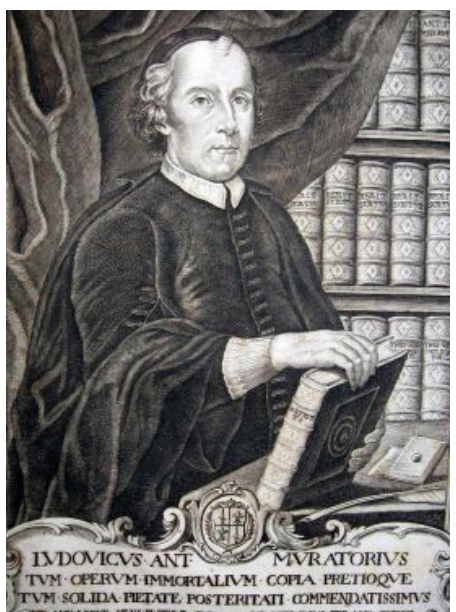

2. kép: Ludovico Antonio Muratori, a milánói Ambrosiana Könyvtárában

$\mathrm{Az}$ itáliai teológus szellemisége lényegében belesimult ugyan a poszttridentinus trendjébe, több esetben mégis akadtak vitapartnerei, akik túlzásnak tartották újszerü nézeteit, indexre kívánták tétetni egyes műveit, $s$ csak hosszas eszmecserék után sikerült ezt elkerülni. Erről bőségesen értekezett az olasz szakirodalom. A kora kereszténység tiszta erkölcsiségét, az aszkétikus spiritualizmus követelményét, a formalitások túlsúlyától és babonás hiedelmektől megszabadított kegyességi gyakorlatot, a társadalmi szolidaritást és az életvitel pallérozottságát sugalló felfogása Eszterházy Károly mentalitására is félre nem ismerhető hatást gyakorolt.

A római kúria vezetésében is jelentékeny változások következtek be a 18. század közepétől. Ezeknek kezdeményezője elsősorban az új pápa, XIV. Benedek (Prosper Lazaro Lambertini) volt, aki úgy maradt lényegileg hủ a trienti szellemhez, hogy közben saját kora kihívásaira is érvényes válaszokat keresett és tudott adni. ${ }^{16} \mathrm{~A}$ szakirodalomban jól ismert Riforma lambertiniana a hit és a tudomány integrálási törekvésiről szólt, s a teológiai racionalizmus jegyében fogant. ${ }^{17} \mathrm{~A}$ tudományoknak nagy szerepet tulajdonító, saját munkáival kisebb könyvtárat megtöltő egyházfö az újskolasztika helyett az empirikus módszereknek igyekezett helyet adni a szellemi élet minden területén, egyetemi reformokat kezdeményezett, laboratóriumok, mühelyek, botanikus kertek, könyvtárak szervezését támogatta, jelentős Index-revíziót hajtott végre, melynek következtében Kopernikusz is lekerült a tiltólistáról. A pápa az eretnekké nyilvánítások és kiátkozások

15 Bitskey István: Püspökök, írók, könyvtárak- Egri föpapok irodalmi mecenatúrája a barokk korban. Eger 1997. (Studia Agriensia 16), 89-118.; Holl Béla: A teológiai gondolkodásmód alakulása a kora felvilágosodás kori magyar katolikus papság könyvkultúrája tükrében. In: Uö.: Laus librorum. Válogatott tanulmányok. METEM, Bp. 2000. (METEM Könyvek 26), 169-180.; Szelestei Nagy László: Ludovico Antonio Muratori művei Magyarországon a 18. század második felében. In: Magyar Könyvszemle 116 (2000), 27-42.

16 Maria Teresa Fattori: The Concil of Trentin the Eighteenth Century: Benedict XIV's De synodo dioecesana. In: Das Konzil von Trient i. m. 417-459.

17 A róla szóló könyvtárnyi szakirodalomból mértékadó áttekintés: Mario Rosa: Between the Council of Trent and Enlightenment: Pope Benedict XIV. In: A Companion to the Catholic Enlightenment in Europe. (Ed.) Ulrich L. Lehrner - Michael O’Neill Printy. J. Brill, LeidenBoston 2010. 224-232. 
helyett az eszmecseréket preferálta, az Unigenitus-bulla ellenzőivel szemben türelmes magatartást tanúsított, így a janzenizmusról szóló vitáknak teret engedett, felélénkítve az egyháztani kérdésekről szóló eszmecseréket. A Muratori-féle „caritas cristiana” eszméje is széltében hódított ebben a szabadabb légkörben, a vakbuzgóság túlkapásait fópásztori rendelet igyekezett beszüntetni, a hitélet egyes kiüresedett formalitásai helyett a gyakorlati kegyesség fontosságát hirdette. A sok tekintetben racionális gondolkodású pápa felismerte a kor követelményeit, a felvilágosodás előterében megjelent különféle gondolatokat, és mindet megtett annak érdekében, hogy a katolikus tudományosság alkalmazkodjék hozzájuk.

Ez a pápa fogadta és bocsátotta útjára a fiatal Eszterházy Károlyt római tanulmányainak végeztével, így érthető, hogy a lambertiniánus szellem egész karrierje során végig is kísérte tetteit és törekvéseit. Eger főpásztora egész pályafutása idején szoros kapcsolatban maradt a római kúriával, ágensei révén frissen tájékozódott az ottani hírekről és véleményekről, s arról is gondoskodott, hogy egyházmegyéjéből fiatal alumnusokat küldjön az Örök Város tanintézetébe, a Collegium Germanicum Hungaricumba. Egyetemalapító és könyvtárfejlesztő tevékenysége, művészeti mecenatúrája és tudománypártolása egyaránt eleven példája a római hatások hazai érvényesítésének. ${ }^{18}$

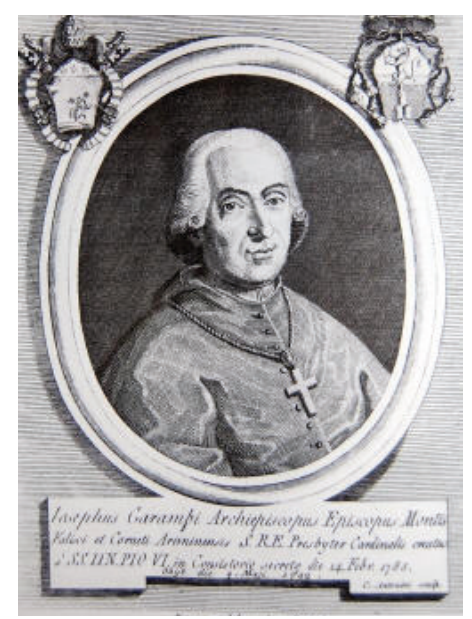

3. kép: Giuseppe Garampi bécsi nuncius

Lényegében ezt a lambertiniánus szellemet képviselte Giuseppe Garampi bécsi nuncius is, akivel az egri püspök közismerten szoros kapcsolatot tartott fenn, a könyvbeszerzésekben ő volt a legbefolyásosabb szaktanácsadója. A római kúria egyházpolitikáját hajlékony diplomáciával, korszerű eszközökkel szolgáló, a racionális teológiai irányzatokat árnyaltan szemlélö, a bécsi jozefinista körökkel is taktikus kapcsolatokat ápoló olasz föpapnak Eszterházyhoz füződő baráti viszonya nem csekély mértékben befolyásolta az egri püspökség szellemi orientációját. A két fôpap kiterjedt levelezésének mielőbbi kiadása nem csupán a helytörténet, de az egész magyar egyháztörténet számára is kiemelkedően fontos kutatási feladat.

18 Minderről részletesen: Eszterházy Károly Emlékkönyv. Szerk. Kovács Béla. Érseki Gyűjteményi Központ, Eger 1999; valamint Az egri Domus Universitatis és Líceum. Szerk. Petercsák Tivadar. Líceum Kiadó, Eger 2013. 
Visszatérve fejtegetésünk kiindulópontjára: Peter Hersche fent vázolt koncepciója szerint Eszterházy Károly korában a teréziánus-jozefinista egyházpolitika kínált volna alapvető megújulási lehetőséget a Habsburg Monarchia katolikus klérusa számára. Az újabb kutatók közül többen úgy látják, hogy korántsem egyházellenességet kellene látni a jozefinizmusban, hanem épp a reformok révén a modernizálás útját jelentette volna a felvilágosodás racionalizmusának, gyakorlatiasságának hitéleti recepciója, ha Wenzel Anton von Kaunitz, Gerhard van Swieten, Ignaz Felbinger, Franz Stephan Rautenstauch és eszmetársaik gondolatvilágát átvette volna a katolikus egyház. ${ }^{19} \mathrm{E}$ feltevés szerint olyan reformok valósulhattak volna meg, amelyekről már a trienti kardinálisok reformpártja is töprengett, csakhogy akkor - mint ismeretes - nem az ő álláspontjuk jutott diadalra; a reformációtól, a „tévtanoktól” való félelem a rigorózusabb nézeteket konzerválta.

Sok szempontból szemben áll ez a fejtegetés az eddigi szakirodalommal, nyilván számos vitát fog még kiváltani az egyháztörténészek körében. Ma már nehéz lenne eldönteni, hogy az osztrák államegyházi elképzelések és szándékok megvalósulása milyen helyzetet idézett volna elő, hiszen a kérdés maga is történelmietlen. A szélesebb történeti kontextus fényében érthetőnek és logikusnak ítélhető válasz született a jozefin államegyházi törekvésekre, nem véletlen, hogy a magyar katolikus klérus szembeszegült az észelvű újításokkal, az egyházszervezeti keretek gyökeres átalakításával, s nem csupán tradicionális Róma-hüsége miatt, hanem az ezekkel együtt mozgósított offenzív németesítési tendencia miatt. Joachim Bahlcke monográfiája meggyőző érveléssel, adatokban gazdag fejtegetés révén mutatja be azt az utat, amely a bécsi udvar és a magyar klérus viszonyában a partnerségtől a konfrontációig vezetett. ${ }^{20} \mathrm{~A}$ bécsi udvar és a római kúria közötti feszültség idején - különösen a pápa 1782. évi bécsi látogatása alkalmával - Eger püspökének álláspontja egyértelműnek bizonyult, a Szentszéket tekintette mérvadónak, s ezen még az sem változtatott, hogy II. József ekkor a Szent István-rend nagykeresztjével tüntette ki őt. Ez az uralkodói gesztus kívánta volna leszerelni az egyházpolitikai ellenfelet, Eszterházy azonban következetes maradt a pápai irányvonal által képviselt és a magyar rendi alkotmányra hivatkozva is védelmezhetó állásponthoz, amely a püspöki jogköröket korlátozó államegyház intézményét ellenezte.

Az utóbbi évtizedek kutatásainak köszönhetően ma már egyértelműen látszik, hogy a felvilágosodás különféle eszmeáramlatainak több komponense az egyes

19 Anton Schindling - Dennis Schmidt: Trient, die katholische Aufklärung und der Josephinismus. Anpassung und Ablehnung in Widerstreit. In: Das Konzil von Trient i. m. 461-486.

20 Joachim Bahlcke: Ungarischer Episkopat und österreichische Monarchie. Von einer Partnerschaft zur Konfrontation (1686-1790). F. Steiner, Stuttgart 2005. (Forschungen zur Geschichte und Kultur des östlichen Mitteleuropa, Bd. 23), föként 301-306. Magyarul: A magyar püspöki kar és a Habsburg Monarchia. Együttműködéstől a konfrontációig (1686-1790). Ford.: Fazekas István. METEM, Bp. 2013. 
közép-európai felekezeti kultúrák mintázataiban megmutatkozott. Eszterházy korának katolikus egyházi műveltségében is szembeötlőek a korszellem egyes megnyilvánulásai, ezt tükrözi az általa alapított reprezentatív püspöki bibliotéka gazdag állománya, amelyben a humanistáknak, reformátoroknak, a felvilágosodás klasszikusainak, janzenistáknak és filojanzenistáknak, természettudósoknak és reformteológusoknak, neosztoikus moralistáknak és egyháztörténészeknek a könyvei egyaránt helyet kaptak. ${ }^{21}$ A könyvbeszerzésekben megmutatkozó tudományos igényesség, sokszínűség és választékosság is jelzi, hogy az új kihívások felismerésében Eger püspöke a legaktívabb fópapok közé tartozott. ${ }^{22}$ Római tanultsága révén egyfelől erősen kötődött a trienti szellemhez, ennek látványos prezentálása a könyvtárterem freskója, másfelől azonban - főként egyetemalapítása révén - élénken reagált a kor tudományos kihívásaira, a „riforma lambertiniana” szellemiségére. Túlemelkedett a tradicionális ausztrokatolicizmus szintjén, a többek között Padányi Bíró Márton által képviselt intranzigens felekezetiség hadállásain, $s$ az újabb teológiai-filozófiai irányzatok iránt fogékonyságot mutató fôpapok közé tartozott. ${ }^{23}$ A felvilágosodás századának bonyolult intellektuális viszonyai, hitéleti és egyházpolitikai lehetőségei és buktatói között úgy tájékozódott, hogy egyházkormányzati tevékenységével időtálló értékeket hozott létre, maradandó létesítményekkel gazdagította - saját felekezetén túl is - a magyar oktatás, tudomány és műveltség ügyét.

21 Tüskés Gábor: A felvilágosodás változatai. Diskurse der Aufklärung (1750-1800). Kiállítás az Egri Főegyházmegyei Könyvtárban, 2008. okt. 9-31, Eszterházy Károly Főiskola, Eger 2008. 3-8.

22 Az Eszterházy-éra alatt Egerben kiadott könyvekről vö. Mizera Tamás - Nagy Andor - Verók Attila: A könyvkiadó egri líceum. Történet és kiadványjegyzék. I. köt. Budapest-Eger 2017. 116-303.

23 Bablcke: Ungarischer Episkopat i. m. 242-244. 


\section{Katholische Erneuerungsbewegungen in der Zeit des Bischofs Károly Eszterházy}

Nach den jüngsten Forschungen über die europäische katholische Kirchengeschichte gab es drei historische Periode, die eine reale Möglichkeit der religiösen Erneuerungen mitbrachten. Nach der posttridentinischen Periode stand der Katholizismus in der Zeit der Aufklärung wieder vor neueren Herausforderungen. Neue Frömmigkeitsauffassungen und neue kirchenpolitische Gedanken erschienen, wie z. B. Jansenismus, Muratorianismus und Josephinismus. Die römisch-katholische Kirche stand vor einem Scheideweg: werden diese Reformideen angenommen oder werden sie abgelehnt. Der Bischof von Eger/Erlau blieb treu den tridentinischen Prinzipien, aber er beabsichtigte in erster Linie die Wissenschaften zu fördern. Seine Vorbilder waren Carlo Borromeo, Ludovico Antonio Muratori und Prosper Lambertini (Papst Benedikt XIV.). Unser Gedankengang versuchte darzustellen, dass Eszterházy's Tätigkeit sowohl auf dem Gebiet der Kirchenpolitik, als auch in der religiösen Kultur und Wissenschaft eine Rolle von nationaler Bedeutung einnahm.

\section{Snahy katolíckej obrody v období Karola Eszterházyho}

Výskum dejín katolíckej cirkvi ožil v ostatných rokoch v európskom meradle. Zároveň prešiel obnovou tak $\mathrm{z}$ metodického hladiska, ako aj $\mathrm{z}$ hladiska svojho pohl'adu. Pozornost' sa namiesto zaužívanej schematickej dichotómie reformácie protireformácie zamerala na pluralitu obrodových hnutí. V tomto kontexte sa ocitol v novej pozícií aj výskum katolíckych obrodových snáh. Katolicizmus sa v období po Tridentskom koncile stretával $s$ takými prúdmi obrodenia, ako janzenizmus, muratorianizmus a jozefinizmus. Rímskokatolícka cirkev stála pred vol'bou: prijme tieto reformné prúdy, alebo ich odmietne. Karol Eszterházy nadalej zostal verný tridenstkému duchu, $\mathrm{k}$ čomu zodpovedajúc výnimočným spôsobom podporoval vedu i umenie. Jeho osobnými príkladmi boli sv. Karol Boromejský, Ludovico Antonio Muratori a Prosper Lambertini, t. j. pápež Benedikt XIV. Štúdia vyzdvihuje činnost́ biskupa Eszterházyho na poli cirkevnej politiky, kultúrneho i vedeckého života a objasňuje jeho význam v kontexte Uhorského královstva. 